Corresponding Author:

Nangkula Utaberta

nangkulautaberta@gmail.com

Received: 2 May 2020

Accepted: 4 July 2020

Published: 14 July 2020

Publishing services provided by Knowledge E

(c) Mohd Tajuddin Mohd Rasdi et al. This article is distributed under the terms of the Creative Commons Attribution License, which permits unrestricted use and redistribution provided that the original author and source are credited.

Selection and Peer-review under the responsibility of the ICIEHI Conference Committee.

\section{An Historical Study of The Ministry of Federal Territories building in Putrajaya within the Perspective of the Discourse on the National and Islamic Architectural Identity of Administrative Architecture}

\author{
Mohd Tajuddin Mohd Rasdi ${ }^{1}$, Kavin Kanesh', Nangkula Utaberta ${ }^{2,3}$, and \\ Nayeem Asif ${ }^{1}$ \\ ${ }^{1}$ School of Architecture and Built Environment, FETBE, UCSI University, Cheras, Malaysia \\ ${ }^{2}$ Halal Products Research Institute, Universiti Putra Malaysia, Selangor 43400 \\ ${ }^{3}$ Research Development Centre, Linton University College, Negeri Sembilan, Malaysia
}

\section{Abstract}

The establishment of a new administrative center in Putrajaya, offered an opportunity to address and to reaffirm a national architectural identity. This research attempts to document and evaluate the design direction of administrative buildings in Putrajaya in response to the issue of establishing a national architectural identity. This paper attempts to analyze the various inputs towards achieving the desired image, from the political, socio-cultural and economic contexts. Additionally, this study considers the thoughts and standpoint of the architect that was in charge of the design for the selected administrative building. This research uses a historical architectural interpretative methodology to analyze the building in situ along with literature reviews and interviews with key stakeholders. The data obtained and presented reveals the underlying issues and convictions that contributed to the formation of a national architectural identity. The research demonstrates how the architect's design sought to emphasise the local and Islamic characteristics and thereby highlight the role of Islam within the new administrative center of Malaysia. This research will provide a critical approach to evaluate the underlying issues which help to form a national architectural identity.

Keywords: National architecture identity, Putrajaya, Administrative building, Menara Seri Wilayah, Kementerian Wilayah Persekutuan

\section{Introduction}

This research paper is intended to document the historical aspects of a selected administrative building in Putrajaya in order to understand and determine the architectural styles, spatial planning as well as typologies that were used to address the national architecture identity that Putrajaya intended to capture. The administrative buildings of 
Putrajaya provide a valid discourse on the issue of national architecture identity as it encapsulates the main architectural identity direction that Malaysia aimed to achieve. Firstly, the administrative building that is selected for the case study will be physically documented and to examine the physical attributes that correlates to translating the idea of a national architecture identity. To obtain a better understanding of how the idea was translated physically, the role of the architect is crucially taken into consideration. His or her understanding as well as stand point towards the idea of a national architecture identity forms much of the physical elements of the building's design elements. Besides providing important information of the selected administrative building and its relating course in addressing the architecture identity, such a research will lay the framework of future design approaches especially in public buildings as well as governmental administrative buildings. Additionally, the research also aims to establish and reaffirm the scope that can contribute towards creating a more cohesive architecture language that is easily perceived by the general mass of the public in order to be relatable and appreciated as a building that serves its intended function.

\section{Background Issue}

Since the formation of Malaysia, the nation has experienced a steep development path that eventually led us to the formation of Putrajaya as the new administrative center of the country. Much of our historical background showed a rather limited and restricted nation, typical of a colonized country. Policies that were laid in place were often to the benefit of the colonial power in order to suppress the nation. To gain independence required a strong foundation with a united forefront. The diversity and multiculturalism of the people was no longer a weakness but rather a strengthening point. As the social, cultural and political scene had a clear translation into the architecture that subsequently developed, the idea of a national architecture identity had a clear correlation with the complex structure of the socio-political state. Early administrative buildings showed a strong universal value that appeased the newly formed social structure. In a more recent context, the formation of Putrajaya was a new turning point for the country as a whole. Similarly, the architecture that was built were a translation of the new sociopolitical order. The architecture of Putrajaya was intended to capture the new idea of a national architecture identity, one that can be projected internationally in order to redefine Malaysia as a developing nation. However, this idea is a cumulative formation of thoughts shared by those who were in charge on the development of Putrajaya and its relating administrative buildings. The research intends to break down the idea of 
a national architecture identity through its various stages of formation. As Putrajaya was very much a governmental lead development, the political stand that was taken is crucial, as well as how this idea is transcended into the physical structures that are now in place, via the role of the architect and his or her relating ideas as well as background towards addressing a national architecture identity.

\section{Objectives of Research}

The objective of the research is to document the relevant design elements used in the selected administrative building case study in Putrajaya, such as massing, form, material usage, ornamentation, structural expression as well as spatial planning in order to address the idea of a national architecture identity. In order to form a better comprehension of the implementation of the design elements, the process of translating the design brief of the selected building from the client's perspective through the ideas and thought processes of the architect in charge will be documented. Additionally, the design elements were studied on how it responded to the regional characteristics of the specific site as well as socio-cultural context in order to strengthen its identity. With the data obtained, a clear direction of the project conception as well as implementation can be clarified. This is in hope to discover the pathway taken in addressing the idea of a national architecture identity during the implementation of the development of Putrajaya and the relating administrative buildings in particular. This will subsequently provide information to architects and planners of future administrative as well as public buildings on the necessary considerations that should be taken during the design process.

\section{Literature Review}

Putrajaya as the new administrative center of Malaysia has been a subject that was extensively discussed and researched upon, to better understand the approach towards urban planning as well as the reasons and requirements that sparked the birth of the new city. Among others, the research entitled "Putrajaya - Administrative Centre of Malaysia - Planning Concept and Implementation" by Ho Chin Siong, extensively discussed the conception of Putrajaya. The research is fundamental to understand what were the features that was implemented for the city and how each piece of architecture that followed, were equally planned for to carry the same ideas and aspirations. The vision for the creation of a new Federal Government Administrative center chose a development 
theme entitled "City in a Garden - Intelligent City". Among others, one of the primary considerations for the new city was for it to carry a distinct image, character and identity. This translates into each administrative building that was subsequently built. In order to document an individual building, understanding its role in the bigger picture of its urban setting is similarly crucial. However, there are fewer researches conducted to mainly identify the approaches taken in specifically creating an image, character or identity. This is an aspect that is being documented in this research paper to identify the architectural forms, design elements, spatial planning as well as considerations that were taken within a specific administrative building that is chosen for a case study. The suitability of these elements within administrative buildings can then be evaluated for further researches or as a reference for creating an identity for future public or administrative buildings in Malaysia.

\section{Methodology}

In order to achieve the objectives of the research, the methodology used in this research is to establish a historical research. The data that is obtained and presented in this paper are collected via content analysis of literature reviews as well as historical research of matters that relate to administrative buildings in Putrajaya as well as the national architecture identity. To further support the research, a case study was conducted in an attempt to document the data via:

1. Site visitation of the selected administrative building in Putrajaya.

2. Physical observation of the selected building with detailed description of the building in terms of architecture style, massing, ornamentation, and expression.

3. Obtaining information of the architect in charge of the design of the selected building and to conduct a subsequent structured questionnaire or interview.

4. Obtaining information of the client or civil servant in charge of the development of the selected building and to conduct a subsequent structured questionnaire or interview.

A structured faqce-to-face interview was conducted with the architect and Tun Dr. Mahathir to understand the approach towards addressing the idea of a national architecture identity.

The subsequent data obtained from the observation, questionnaire or interview as well as literature reviews form the findings of this historical research documentation of 
the administrative building in Putrajaya as well as the attempt of addressing the national architecture identity.

\section{Research Findings}

This section documents the findings of the selected case study building in terms of its physical attributes and spatial planning. Subsequently, the thoughts and ideas of the architect in charge will be documented in order to relate them to the physical evidence. It is also supplemented by the requirements of the civil servant that conveyed the aspirations of the government through its new administrative city planning.

\subsection{Case study: Basic description of building, ornaments and expression}

The building that was selected for the case study is the Menara Seri Wilayah, which is where the ministry of federal territories (Kementerian Wilayah Persekutuan) is housed. It is located on parcel 2C1 (phase 1) and a portion of parcel 2C2 in Precinct 2 of Federal Territory of Putrajaya. This building was designed by the architect firm Kumpulan Senireka Sdn. Bhd. The firm is one of the most established firms in Malaysia that was founded in 1973. In terms of its site location, it is located directly opposite the Finance Ministry and overlooks the Prime Minister's office as well as the Putra Mosque (Figure 1). It is also strategically located at a vantage point along the administrative boulevard on the core island of Putrajaya.

Menara Seri Wilayah was completed towards the end of 2003 and was the first commercial office building development in Putrajaya. Initially, it was known as Menara $\mathrm{PJH}$ as it was intended to be the new headquarters of Putrajaya Holdings Sdn Bhd, the master developer of Putrajaya (Cheah, S. (2003). Special features of Menara PjH. The Star. [online] Available at: http://www.thestar.com.my/business/business-news/2003/ 09/29/special-features-of-menara-pjh/ [Accessed 15 Mar. 2017]). This development comprises of 2 blocks, an 8 storey north block and a 10 storey south block with an additional 2 levels of basement for parking spaces as well as a cafeteria on the lower ground level. With the main tenant of Putrajaya Holdings Sdn. Bhd. and later on, Kementerian Wilayah Persekutuan located in the south block, the north block was designed as office space to be rented out to various tenants. The north block comprises of $144,433 \mathrm{ft}^{2}\left(13,418 \mathrm{~m}^{2}\right)$ of net office space with a typical ceiling height of 2.7 meters (Kumpulan Senireka Sdn. Bhd (2001) Site plan of Putrajaya holdings 


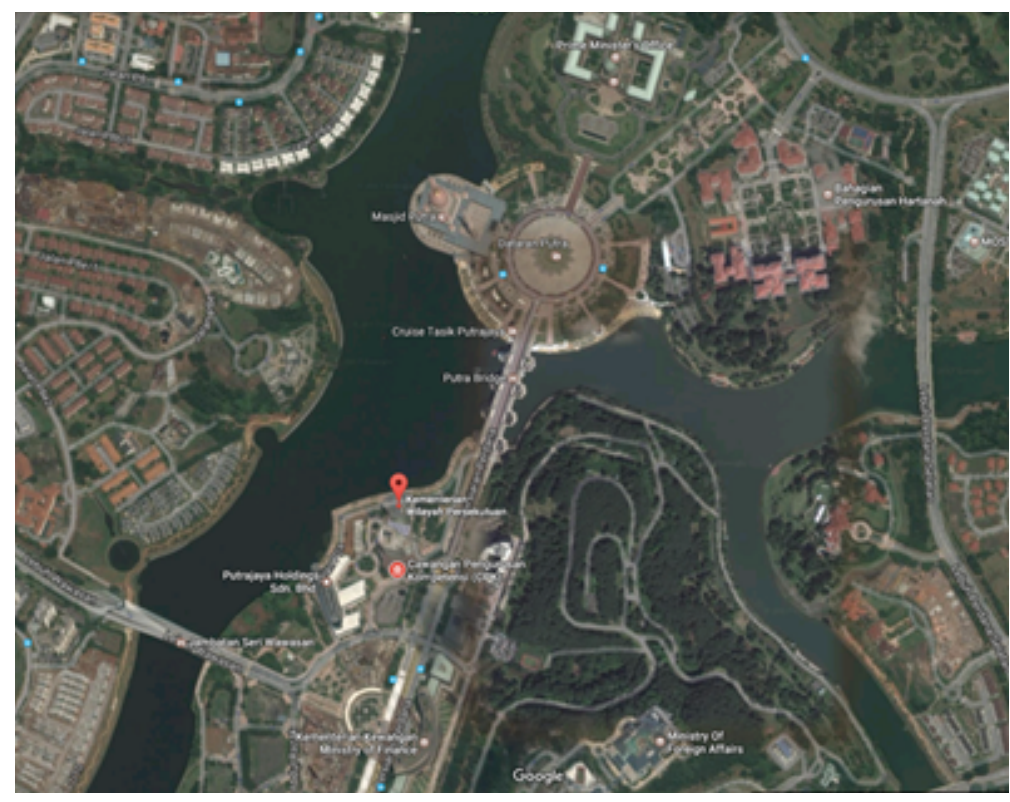

Figure 1: Location plan of Menara Seri Wilayah. (Source: google maps)

Sdn. Bhd Complex. Jabatan Perancangan Bandar, Perbadanan Putrajaya, Putrajaya). The building was designed as an intelligent building that boasts an array of state of the art technological advancements during its time of construction, and at the same time commanding lake views with green landscapes. Some of the features that can be observed are the notable exterior finished with colored granite, raised floors, and generous landscaped gardens (Figure 3).

Architecturally, the post-modernist architectural concept that was used had the intention of projecting an overall sense of strength, permanence and solidity (Cheah, S. (2003). Special features of Menara PjH. The Star. [online] Available at: http://www. thestar.com.my/business/business-news/2003/09/29/special-features-of-menara-pjh/ [Accessed 15 Mar. 2017]). The overall design approach utilizes Islamic features as well as to suit local conditions with additional features such as covered walkways, proper orientation and sun shading devices to tackle the tropical climate. In terms of spatial planning, the 2 blocks are joined via a central atrium space covered with a large skylight with high headroom that is naturally ventilated (Figure 3). This atrium serves as an exhibition space and is publicly accessible. The circulation is aided by a perimeter corridor that connects the interior spaces to the exterior spaces, which are surrounded with lush landscapes. This corridor is expressed by being set in and covered with sun shading devices that can be seen throughout the exterior. This notable characteristic is constructed in steel to form an Islamic geometric pattern in order to prominently portray the Islamic features. Additionally, the terraced gardens that surround the building is 


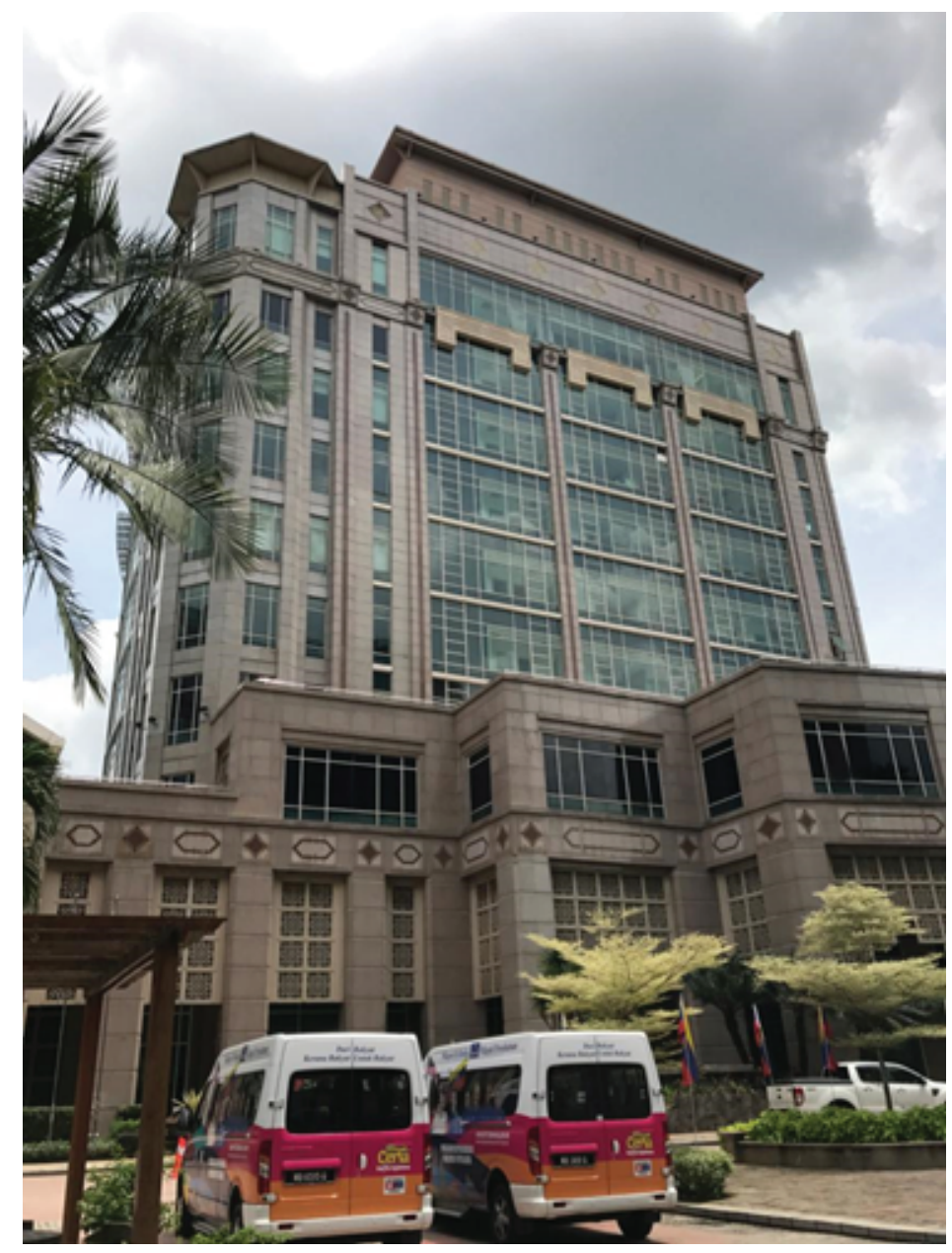

Figure 2: Exterior characteristics and generous landscaping (Source: Kanesh, K., 2017. Exterior view. [Unpublished photograph]).

heavily expressed as a tropical feature. Numerous characteristics found in this building are reinterpretations that are similarly found in other notable works by the architect in charge, such as the Putra Mosque and Dataran Putra. These are distinct features of the building that expressed its character.

In order to better understand the design direction taken during the conception of Menara Seri Wilayah, an interview was done with the architect that was in charge of the building. The architect that was tasked with the design of this building was Ar. Abu Hanapiah bin Mohd Ali, a partner in Kumpulan Senireka sdn. Bhd. He has now gone on to establish his own firm, as he had left Kumpulan Senireka sdn. Bhd. for more than 10 years, coincidently right after the completion of Menara Seri Wilayah. As he was involved form the beginning of the design of the building, some 3 to 4 years prior to its completion, it is a valid source of identifying the design direction taken. A structured 


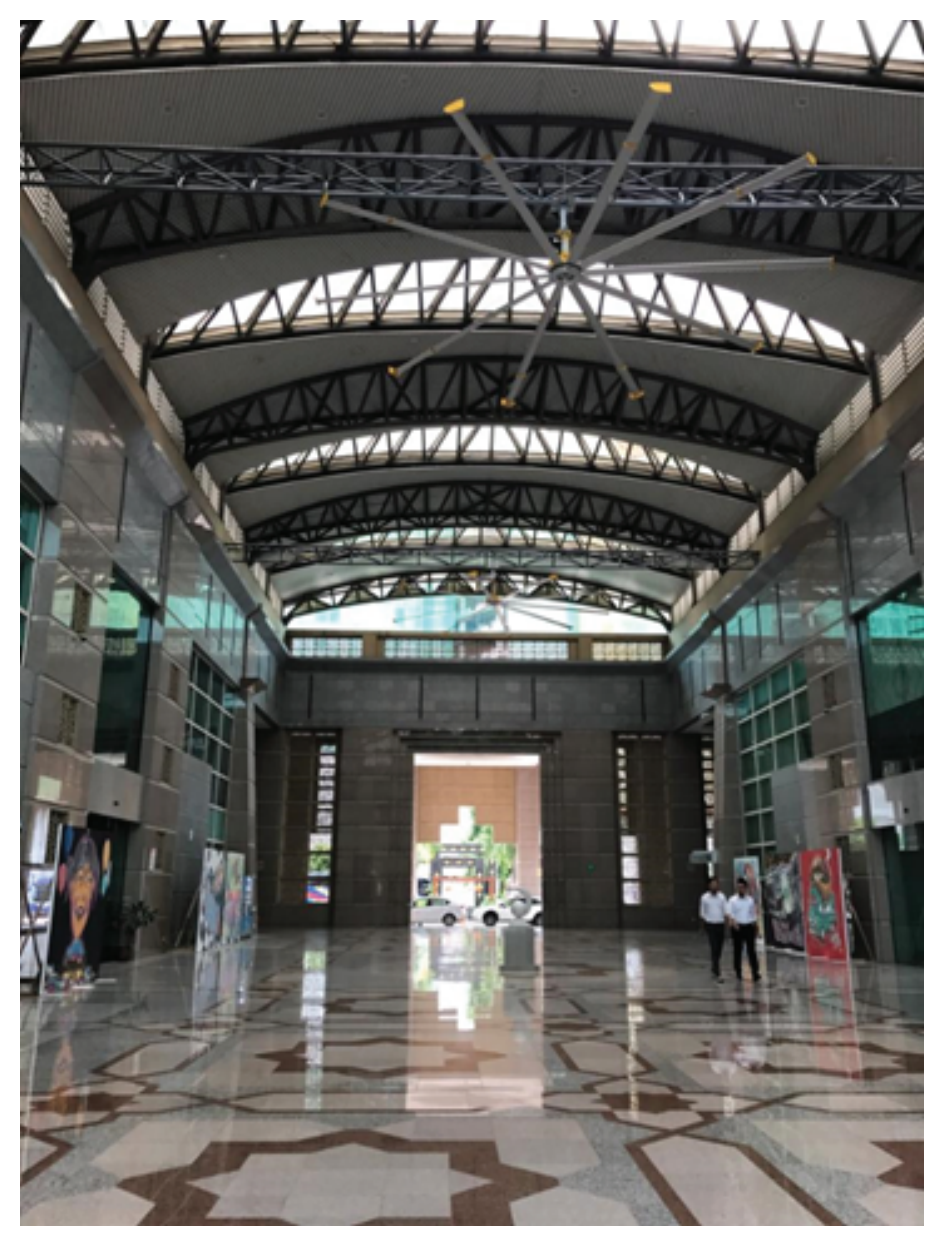

Figure 3: Large central atrium space (Source: Kanesh, K., 2017. Atrium view. [Unpublished photograph]).

interview was conducted with Ar. Abu Hanapiah via email correspondence to obtain his views of the issue of research.

According to him, the building was set out as a requirement of the client, Putrajaya Holdings Sdn. Bhd. to relocate their entire headquarters from a temporary building that was located in an oil palm plantation estate in Prang Besar, which is now known as Putrajaya (Mohd Ali, A. H. (2017). Idea of a national architectural identity). The usage was to accommodate the main sales office, exhibition hall, conference facilities, a multipurpose (banquet) hall, food court and corporate offices. The development was to adhere to the concept guideline of the UDG (Urban Design Guidelines) which determined the building's master plan, plot ratio, orientation, height limits as well as architectural characteristics. Within the UDG, there was an emphasis on Islamic features which are to be adopted in order to establish a new administrative center for Malaysia which he described as follow: 


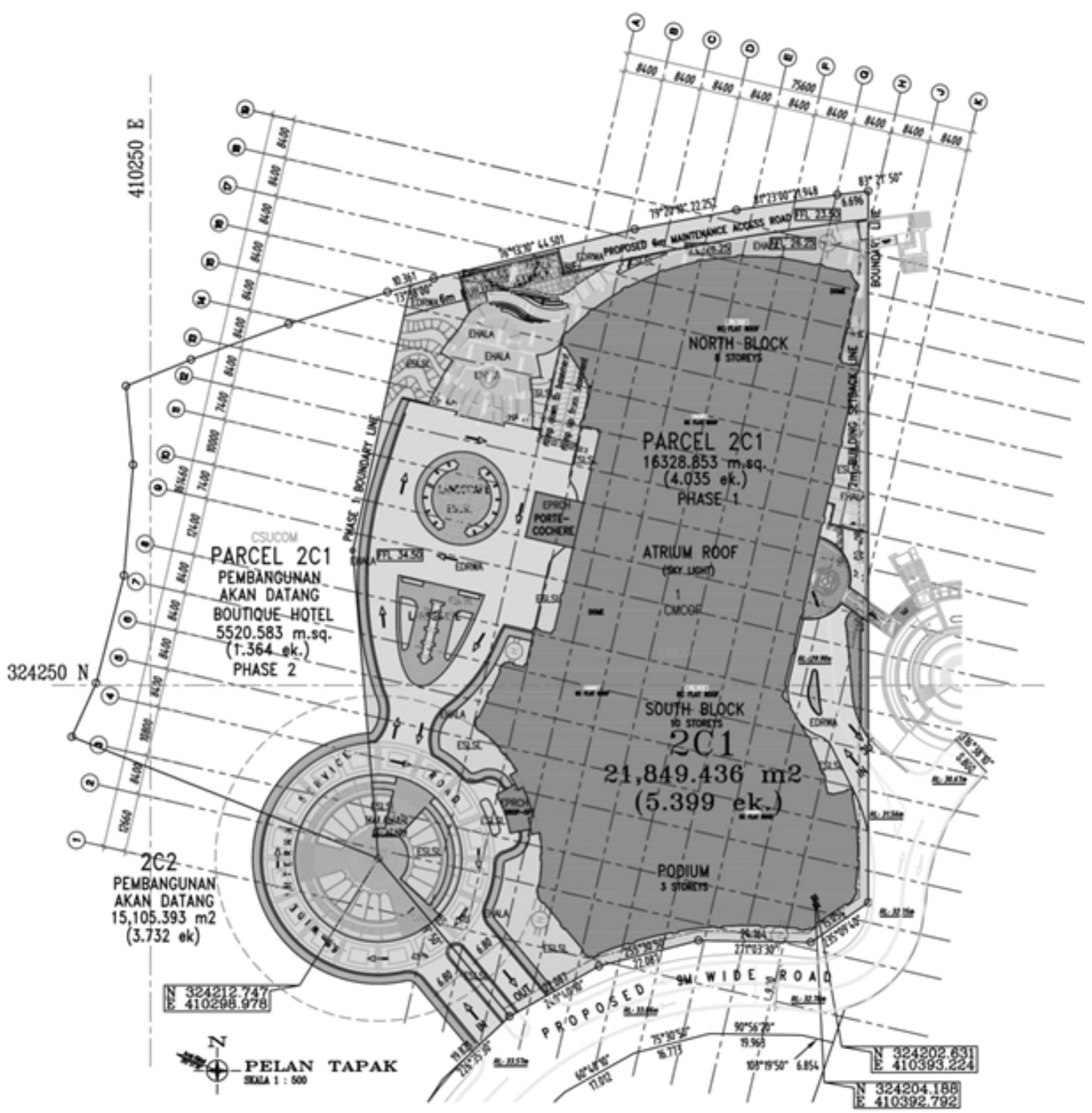

Figure 4: Site plan of Menara Seri Wilayah (Source: Jabatan Perancangan Bandar, Perbadanan Putrajaya)Interview with the architect on his idea of a national architectural identity for the building

"The UDG did emphasise on local and Islamic features to be adopted as it is going to be the new administrative center for Malaysia; an Islamic Country as Islam is its official religion."

In order to achieve these requirements, the building adopted mainly Islamic features in order to enhance the aesthetics (Figure 5). The building was to also suit local conditions with elements such as covered walkways, proper sun orientation as well as to tackle excessive sunlight with the use of sun shading devices (Figure 6).

The client, Putrajaya Holdings, is a governmental arm that was incorporated on Oct 19, 1995. Its shareholders comprised of Petroleum Nasional Bhd (Petronas), Malaysia's 


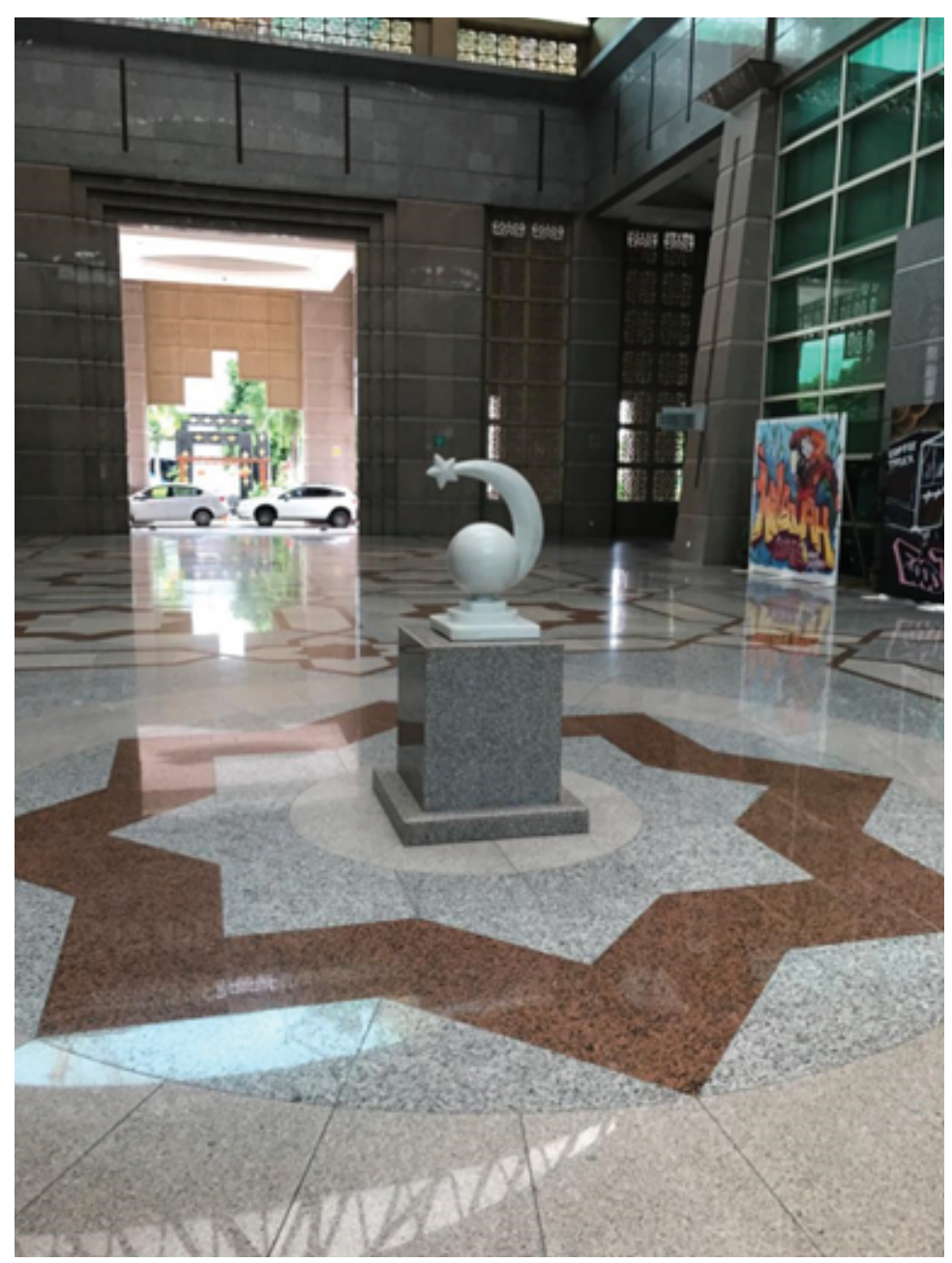

Figure 5: Islamic characteristics found in Menara Seri Wilayah (Source: Kanesh, K., 2017. Atrium view. [Unpublished photograph]).

national petroleum company with $64.4 \%$ equity; Khazanah Nasional Bhd, the investment arm of the Malaysian government with $15.6 \%$ equity; and Syarikat Nominee Bumiputra Pte Ltd, with 20\% equity (Cheah, S. (2003). Special features of Menara PjH. The Star. [online] Available at: http://www.thestar.com.my/business/business-news/2003/09/29/ special-features-of-menara-pjh/ [Accessed 15 Mar. 2017]). The architect reflected on the role and relation of the client's brief and how it relates to the governments plans:

"The client (Putrajaya Holdings) being owned by the government wants to reflect the government aspiration at the time so it's only natural for them to project this identity."

The architect drew inspiration from this and at the same time tied it to past governmental buildings found in Kuala Lumpur that had strong reflection of Islamic and regional characteristics that eventually became iconic due to its distinct character and subsequently became tourist attractions. This is the identity that the architect tried to 
encapsulate from his design as it was one of the first buildings in Putrajaya in the core island. He believed that it would become a precedent for other governmental buildings that were in the pipeline of development. However, Ar Abu Hanapiah is a firm believer that a national architecture and its identity evolves through time as he recollected on the following:

"Yes, we should have one (national architecture identity) but it should evolve with time, not stagnant. But most importantly it must serve its purpose: the end user."

As such, the most important aspect in the architect's point of view is that the building should firstly serve its intended function and purpose, and that translates into the function towards the end user. This was the most critical aspect that he tried to convey in the design of the building.

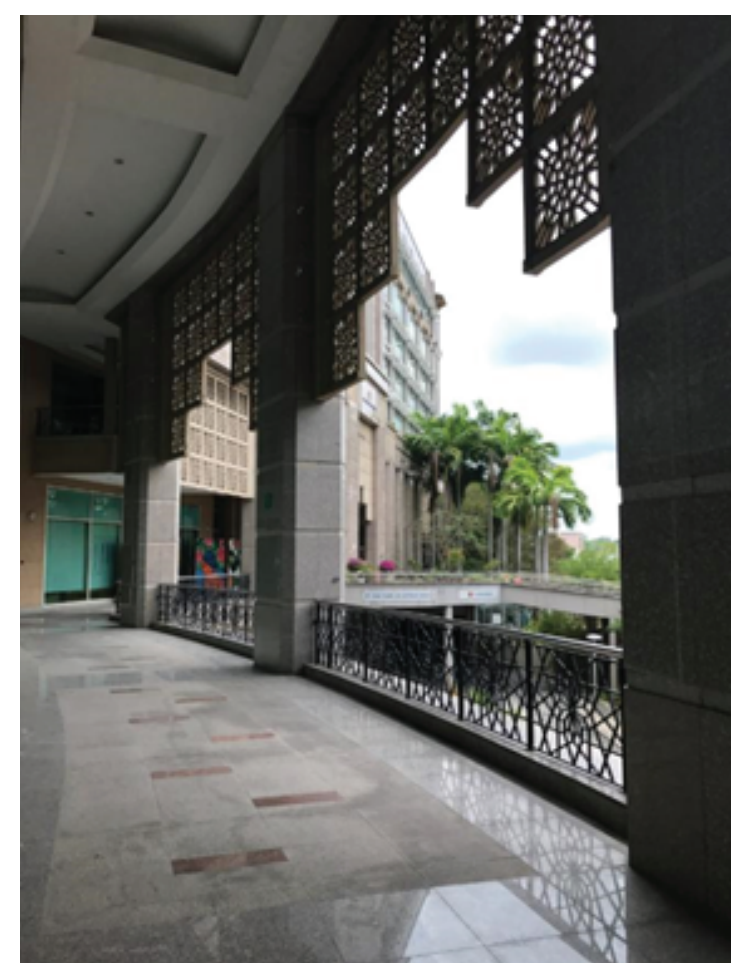

Figure 6: Covered walkways with usage of sun shading devices. (Source: Kanesh, K., 2017. Walkway view. [Unpublished photograph]).

Other important aspects of the design were the idea of regionalism as follows:

"There is nothing wrong with regionalism and it is not right to make it compulsory either. But then you can't design a glass house in Malaysia."

While it may not be compulsory to adhere to this theory, he did pursue numerous aspects of the building within this framework. Some of the features that gave character 
to this building were mainly Islamic features. They can be seen in other notable works surrounding Putrajaya, some from the same architect firm in charge such as Dataran Putra, Putra Bridge as well as the Putra Mosque (Figure 7). To an extent, these features can also correlate to the building of Ministry of Finance, giving it a regional identity (Mohd Ali, A. H. (2017). Idea of a national architectural identity). Those features that was worked on gave the area and subsequent buildings that emerged, its own character. This cluster of buildings at the start of the conception of Putrajaya, work together to give it a distinct character that differs to those that are seen in more recent times.

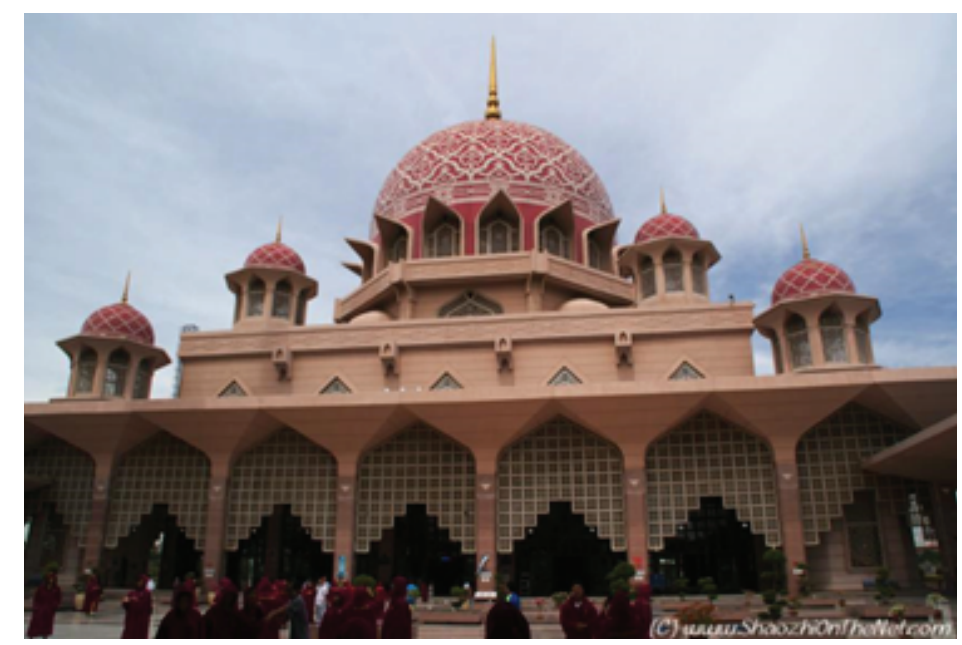

Figure 7: Putra Mosque by Kumpulan Senireka Sdn. Bhd. with similar Islamic characteristics (Source: https: //www.shaozhionthenet.com)

While some of the features that are found in Menara Seri Wilayah were adopted into ornamentation that was used extensively, its function was to emphasize the Islamic character of the building. The architect expressed his views that ornamentation certainly adds to amplify the architectural language of the building to give the design a sense of direction.

"Like I said earlier the features include ornamentation were used extensively to emphasize the Is/amic character. Ornamentation certainly adds to amplify the architectural language. Otherwise we would be building boxes with solids and voids. It can be boring with no finesse."

When presented with the question on how the architect saw his building as being part of the bigger picture in administrative building in Putrajaya and how he perceived the development and design direction of Putrajaya, he reflected that the development of Putrajaya dates back to the 1990's and rather regretfully, we are still searching for the ultimate architecture identity and language to adapt to. Putrajaya stood at a crossroad of fulfilling to local, regional or international needs. In his views, it all boils down to who 
the client was and what was within their design brief. The role of the architect was to also provide a direction for the development, whereby a wise architect would simply not design a Terengganu style pitch roof or flat roof dwellings, If the clients were Eskimos living in the North Pole (Mohd Ali, A. H. (2017). Idea of a national architectural identity). Similarly, he found that presenting an Igloo within a local context is irrelevant. So firstly, the design should appeal towards the client, and as he pointed out that for instance, he must capture the idea that can be relatable to the client, for an example that was cited, Tun Dr Mahathir and his perceived idea of Putrajaya or even his private residence.

As he further reflected, he is proud of the works that he and the firm collectively contributed, such as the Dataran Putra which have become a favorite tourist attraction, as well as some of the surrounding buildings that were also works of Kumpulan Senireka (Figure 8). By adhering to the design principles, it is unlike some of the more modern buildings that is cold and uninviting, which is uncharacteristic of Malaysia. While some architects may like them, it is rather familiar and can exist and be found in any other capital cities of Asia. In that case, it does not give it a distinct character that relates to Malaysia.

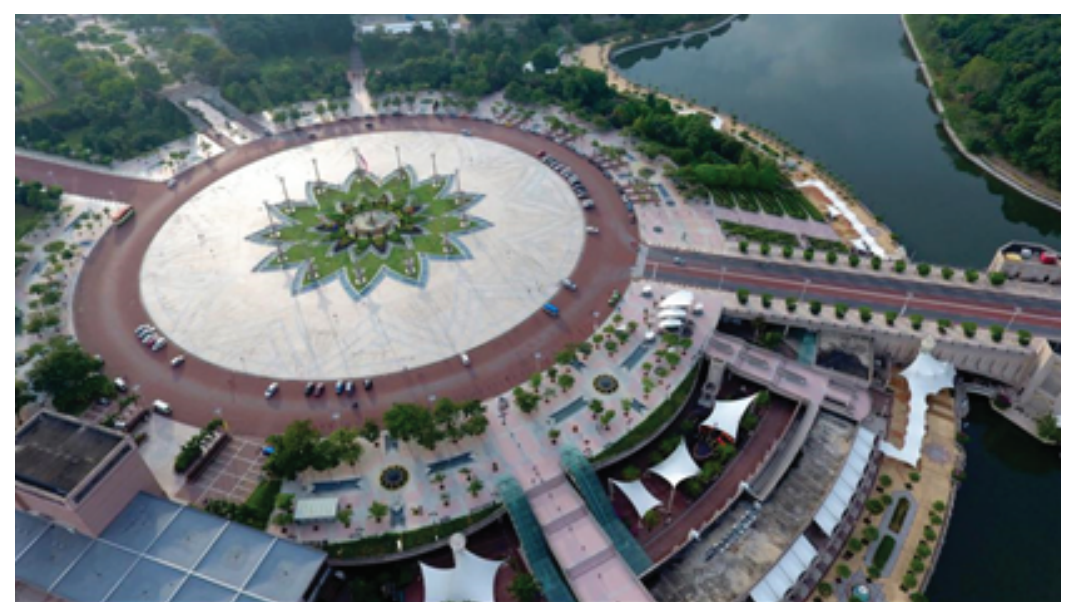

Figure 8: Dataran Putra by Kumpulan Senireka Sdn. Bhd. (Source: Rahman, H., 2016. Dataran Putra Putrajaya. [http://www.harisrahman.com/my-blog/2016/10/13/more-exploration.html])

While Putrajaya have moved on and developed at the rapid rate in the last 20 years, the architect expressed that he is not too concerned about the simple architecture of the building, as it evolves with time as well as policies that are laid in place. His main concern however, is that even though Putrajaya is deemed as a town planning masterpiece, it sadly does not serve its occupants well. This again ties to his most important principle of fulfilling the end user ultimately. In the bigger picture, the city, regardless of the individual architecture, was designed and built more so for cars rather than people. As he rightfully pointed out that there is a distinct lack of people walking 
down the main streets or even see children cycling or playing in the football fields. It also lacks in commercial activities that can serve the city's dwellers. He perceived this as a probable issue that the buildings are planned too far apart, and that results in people needing to drive to get to their destination. This results in an empty city beyond the working hours of the administrations. Maintaining empty cities can and will soon be a burden as it is unsustainable as a city with low density. His aspirations for the future is to relook at ways that can make the city friendlier to the people, as well as innovative ways of utilizing empty spaces to link man, car, buildings as well as landscape. Only after this is addressed, individual buildings and their relating architecture can be more appreciated in its pure intended function, which is to serve the people.

\subsection{Interview with senior civil servant involved in the conception of the building}

While there was no civil servant that was directly involved in the conception of Menara Seri Wilayah available for an interview, there was an opportunity to engage in an interview with Tun Dr Mahathir bin Mohamad In regards to his views of the administrative buildings in Putrajaya as well as his perception towards the issue of a national architecture identity. It is valid and crucial to engage in the views that was held by the then, Prime Minister of Malaysia, who held great responsibility and involvement in envisioning as well as developing the new administrative center of Malaysia. Although he was not directly involved in the building of study specifically, his views and ideas were the direction taken by most designs parallelly in order to achieve a cohesive look for the new administrative center. In the interview with the architect of the building, he had expressed that it was in his intentions to also capture the general ideas that was envisioned by Tun Mahathir for Putrajaya.

In the interview, Tun Mahathir expressed that the architecture of Malaysia should most importantly relate to the regional characteristics. Considerations that are unique can give the architecture character such as climatic responses. Much of Malaysia's heritage architecture had clear climatic responses and that made it unique. For instance, the high-pitched gable roof was design in order to shed heavy rainwater off quickly. In comparison, a flat roof is less desirable for Malaysia's climatic conditions (Mohamad, Dr. M. (2017). An Interview with Tun Dato' Seri Dr Mahathir bin Mohamad on the idea of a national architectural identity).

Additionally, Islamic characteristics was of great importance as it is the official religion of the country. Tun Mahathir had aspired Malaysia to lead Islamic nations globally, 
and subsequently, it must carry important Islamic characteristics such as domes as he described below:

"By adding domes would give Putrajaya a certain character such as the Prime Minister's Office and the Palace of Justice, as well as to reflect the Malay character."

Some of the architecture had references towards other Islamic nations that he drew inspirations from, such as bridges that were designed after those found in Iran, as well as decorations from Morocco and Iranian mosaic motifs. However, as Tun Mahathir did not restrict his views to only Islamic nations, he also reflected on his preferences towards the angular and neat layouts found in Japanese architecture. The common trait that captured his ambitions in all his inspirations are that the designs are unique regionally and did not take after those of western cultures by simply copying.

In terms of the city's layout, the large central divider that creates the central boulevard was designed for large parades and more importantly, for human activities. However, the final designs did not fully capture this desire, as the central boulevard was mainly occupied by governmental buildings that negated human activity beyond working hours. It is still in his vision to see Putrajaya develop further beyond this by incorporating lively human activities throughout the city with buildings that reflect our region instead of large glass boxes and dormant streets (Mohamad, Dr. M. (2017). An Interview with Tun Dato' Seri Dr Mahathir bin Mohamad on the idea of a national architectural identity).

Through the interview conducted with Tun Mahathir, it can clearly be seen that the general concept that he envisioned for the new city was the basic guidelines that most designs took after. It was a cohesive approach taken by all parties involved, from the government through the city's planning policies as well as the architect's designs and implementations.

\section{Discussions and Implications of Findings}

From the findings, there is a clear correlation between the design direction taken as well as the aspirations and ambitions of the government, for Putrajaya as the new administrative center. Each building had its importance within the master layout. While the architecture identity was not clearly defined, or set out to be achieved, there were many aspects that governed the way each design developed and evolved. In more specific terms, the Menara Seri Wilayah also underwent similar processes. From the onset, neither the client nor the architect consciously tried to reflect a specific identity 
through the design or planning. The design brief was targeted towards fulfilling the function of the new building as an office headquarters most importantly. As there were little site constraints, much of the façade was a form of projected image that tried to capture the idea of Islamic architecture characteristics. Additionally, as it is one of the few first constructed buildings, it did not have to stay in context with other surrounding developments. Neither of these are advantages nor disadvantages towards the building's overall design.

As the architect that was in charge of this building had other projects of similar importance within the surrounding area, they set out to form a cohesive set of buildings that relate to one another via similar design characteristics. These buildings were designed within a similar framework by firstly addressing the function as well as end user. In addition, Islamic design elements were extensively used in order to give each building a more distinct character that will enable it to be more iconic and distinguishable. It was also important to be relatable to the end user, partially being the people and governmental staff of Putrajaya. Similarly, Islamic characteristics were chosen in order to convey this message of being relatable to the masses.

As the architect highlighted, is it also fundamental to capture the needs and imagination of the client in respect, in order to fulfill the design brief (Mohd Ali, A. H. (2017). Idea of a national architectural identity). The architect's role is crucial to envision a physical form of various ideas and references that the client envisioned for his or her new building. The architect must be able to perceive designs that he or she thinks are more favorable for the client, as the role of the client is extremely important, to firstly be able to realize the designs that exist on paper, into physical structures. In the case of administrative buildings, the clients are part of the governmental arms that are in charge of various ministries, investments or development plans. In that case, the client is an extension of the government and hold similar perspectives, principles, as well as aspirations. This is crucial in order to translate the position of the government when undertaking the development of Putrajaya from the onset.

All of these various inputs formed the design direction of the building in question. They must all come together in a cohesive manner to form a final product that speaks of the design intentions of, firstly, the government and its relating ministries, and secondly, the architect in charge. If an active attempt in addressing the national architecture identity is taken from all contributing parties, only then will the by-product of this speak of a wholesome architecture identity. 


\section{Conclusion and Further Research}

From the gathered information and documentation on the selected case study, the general process that took place during the planning and implementation of Putrajaya as well as the related administrative buildings can be identified. It is a tedious process that involves various parties who had an interest in the construction of it. The new city was planned within the Urban Design Guidelines that was set out to administer the new development. Administrative buildings were also planned within these guidelines. Beyond that, the governmental arms that were involved, either directly or indirectly, as a client, played a crucial role in conveying the ideas and aspirations that was set out for the new city. The architect, whose ideas and philosophies were a product of his opinions and framework towards addressing a design brief. However, he operates within the larger firm, and therefore he must also carry the design philosophies of the company and their relating background (Mohd Ali, A. H. (2017). Idea of a national architectural identity). As a result, the design that is physically seen on site today is a product of all these various inputs, filtered in a manner of importance. Dominantly, Islamic features was a crucial part that was seen of great importance to the government, and conveyed through the client, as well as the architect and the firm he represents. Some of the most important projects that were done by the firm were Mosques, evidently highlighting their capabilities in addressing Islamic architecture. The approach that was taken in addressing a national architecture identity was not a specific path with a clear direction, Islamic or not. It was a cumulative set of design cues that was formulated over the course of the designing process. Regardless if it was the most effective path taken to create the identity, it was a successful process that formed a piece of architecture that is embedded within the history of Putrajaya, through its administrative buildings. As a piece of historical evidence, a research such as this, can uncover the ideas behind it. It is beneficial for the development of future administrative or public buildings. In terms of future researches, a comprehensive evaluation of the design aspects can be carried out to determine a stronger approach towards formulating a firm national architecture identity. These aspects must be readily available to not just the architects, but to also expand over the entire built industry, as evidently, a client or developer plays a crucial role in the outcome of a design. If the findings of such a research can be encouraged in the practice of all parties, a more wholesome approach can be taken with a common ambition to be addressed, in formulating a concrete national architecture identity. 


\section{References}

[1] The Star. (2003, September). Retrieved March 15, 2017 from http://www.thestar.com. my/business/business-news/2003/09/29/special-features-of-menara-pjh/

[2] Mohd Ali, A. H. (2017). Idea of a National Architectural Identity.

[3] Mohamad, M. (2017). An Interview with Tun Dato' Seri Dr Mahathir bin Mohamad on the Idea of a National Architectural Identity.

[4] Jabatan Perancangan Bandar, Perbadanan Putrajaya. (2001). Site plan of Putrajaya holdings Sdn. Bhd Complex. 